MEDFARM: Jurnal Farmasi dan Kesehatan, Vol. 10, No. 2, 2021, Hal, 1-12

e-ISSN : 2715-9957

p-ISSN: 2354-8487

\title{
EVALUASI PENGGUNAAN OBAT ANEMIA PADA PASIEN PENYAKIT GINJAL KRONIK DENGAN HEMODIALISA DI RSU ARI CANTI PADA TAHUN 2020
}

\author{
Ni Made Maharianingsih ${ }^{1}$, Ni Kadek Sulistya Dewi ${ }^{2}$ \\ 1,2)Prodi Farmasi Klinis, Universitas Bali Internasional, Denpasar-Bali \\ e-mail: ${ }^{1)}$ maharianingsih@iikmpbali.ac.id
}

\begin{abstract}
ABSTRAK
Penyakit ginjal kronik (PGK) menjadi perkara nyata dalam dunia medis dengan peningkatan prevalensi secara terus-menerus. Tindakan medis yang dilakukan pada pasien PGK ialah hemodialisis, tindakan ini dilakukan pada pasien PGK stadium lima dengan nilai GFR $<15 \mathrm{ml} /$ menit, dimana tindakan tersebut bertujuan untuk mengganti fungsi ginjal dalam menyaring dan mengeluarkan racun uremik dalam tubuh. Hemodialisis dapat menimbulkan beberapa dampak yaitu kram otot, hiperkalemia, hipotensi atau hipertensi dan anemia. Anemia yang dialami pasien PGK sebagian besar diakibatkan oleh defisiensi erythropoietin. Penilaian kesesuaian pemberian terapi anemia pada pasien PGK dengan standar yang berlaku menjadi penting untuk mencapai efek terapi yang optimal. Tujuan dari penelitian ini untuk menilai penggunaan obat anemia pada pasien PGK yang sedang menjalani hemodialisis di RSU Ari Canti pada periode Januari-Desember 2020. Penelitian ini termasuk penelitian deskriptif dengan data diambil menggunakan teknik restrospektif yang melibatkan 80 sampel data rekam medis, yang dipilih secara purposive sampling. Pada penelitian ini menunjukan hasil pola pemakaian obat anemia pada pasien PGK yang sedang melakukan hemodialisis mendapat pengobatan tunggal $(73,75 \%)$ dan pengobatan kombinansi $(26,25 \%)$. Obat yang dipakai ialah erythropoietin alfa, iron dan asam folat. Penilaian penggunaan obat anemia pada pasien PGK yang melakukan hemodialisis atas dasar ketepatan pasien (100\%), ketepatan indikasi $(100 \%)$, ketepatan obat $(97,5 \%)$, ketepatan dosis $(100 \%)$, ketepatan interval waktu pemberian $(100 \%)$ dan waspada efek samping $(100 \%)$. Kesimpulannya penilaian penggunaan obat anemia pada pasien PGK yang sedang melakukan hemodialisis di RSU Ari Canti pada tahun 2020 telah memenuhi kriteria ketepatan pasien, ketepatan indikasi, ketepatan dosis, ketepatan obat, ketepatan interval waktu minum obat dan kewaspadaan terhadap efek samping.
\end{abstract}

Kata kunci: Anemia, Evaluasi Penggunaan Obat, Hemodialisis, Penyakit Ginjal Kronik.

\begin{abstract}
Chronic kidney disease (CKD) is a real problem in the medical world with a continuous increase in prevalence. Medical action performed on CKD patients is hemodialysis, This action is carried out in stage five CKD patients with GFR values $<15 \mathrm{ml} /$ minute, namely at stage five, where this action aims to replace kidney function in filtering and removing uremic toxins in the body. Hemodialysis can cause several effects, namely muscle cramps, hyperkalemia, hypotension or hypertension, and anemia. Anemia experienced by CKD patients is mostly caused by erythropoietin deficiency. Assessment of the suitability of
\end{abstract}


MEDFARM: Jurnal Farmasi dan Kesehatan, Vol. 10, No. 2, 2021, Hal, 1-12

e-ISSN : 2715-9957

p-ISSN: 2354-8487

providing anemia therapy in CKD patients with applicable standards is important to achieve optimal therapeutic effects. The objective of this research was to assess anemia drugs uses in CKD suffer with hemodialysis treatment at Ari Canti General Hospital in the period January-December 2020. This research is a descriptive study with data were taken using a retrospective technique involving 80 samples of medical record data, which were selected by purposive sampling. In this study, the outcomes showed the example of utilization of hostile to pallor medicates in CKD patients who were going through hemodialysis getting single treatment $(73.75 \%)$ and blend treatment $(26.25 \%)$. The drugs used are erythropoietin alpha, iron, and folic acid. Assessment of the use of anemia drugs in CKD patients undergoing hemodialysis based on patient accuracy (100\%), indications accuracy (100\%), drugs accuracy (97.5\%), dosage accuracy (100\%), the accuracy of time intervals of administration (100\%) and alert for side effects (100\%). In conclusion, the assessment of the use of anemia drugs in CKD patients undergoing hemodialysis at Ari Canti General Hospital in 2020 has met the criteria for patient accuracy, indications accuracy, dosage accuracy, drugs accuracy, timeliness of taking medication, and alertness to side effects.

Keywords: Anemia, Evaluation of Drug Use, Hemodialysis, Chronic Kidney Disease.

\section{PENDAHULUAN}

Penyakit Ginjal Kronik (PGK) ditandai oleh adanya kelainan struktur dan fungsional ginjal yang berlangsung lebih dari tiga bulan, dengan atau tanpa penurunan Laju Filtrasi Glomerulus (LFG) dan dapat berkembang sebagai kelainan patologis atau kerusakan ginjal (Dipiro et all, 2015). Terdapat sejumlah faktor yang dapat menyebabkan penyakit ginjal kronik diantaranya ialah riwayat penyakit yang diderita sebelumnya seperti hipertensi, DM serta penggunaan obat bersifat nefrotoksik yang berkepanjangan seperti obat anti inflamasi non streroid (OAINS) (Lilia \& Supadmi, 2019)

Penyakit ginjal kronik diklasifikasikan menjadi lima berdasarkan nilai LFG. Semakin rendah nilai LFG menunjukan semakin parah tingkat penyakit pasien. Pada stadium satu nilai LFG pasien menunjukan sebesar $\geq 90 \mathrm{ml} /$ menit yang artinya masih berada pada rentang normal, pada stadium dua nilai LFG menunjukan sebesar 60-89 ml/menit, keadaan ini menyatakan kerusakan giinjal dengan penurunan LFG ringan, pada stadium tiga nilai LFG berada pada rentang 30-59 ml/menit yang artinya terjadi kerusakan ginjal dengan penurunan LFG sedang, pada stadium empat nilai LFG pasien berada pada rentang 15-29 $\mathrm{ml} /$ menit, pada stadium ini menunjukan kerusakan ginjal dengan penurunan LFG berat, dan pada stadium lima yang biasanya dikenal dengan sebutan gagal ginjal, disini nilai LFG pasien sudah berada $<15 \mathrm{ml} /$ menit dan sudah 
MEDFARM: Jurnal Farmasi dan Kesehatan, Vol. 10, No. 2, 2021, Hal, 1-12

e-ISSN : 2715-9957

p-ISSN: 2354-8487

memerlukan terapi sebagai penanganan medis (Pernefri, 2011). Ada beberapa Tindakan medis yang dapat dilakukan pada pasien PGK yaitu transplantasi ginjal dan diliasis, dialisis dapat dibagi menjadi dua yaitu hemodialisis dan peritoneal dialisis. Hemodialisis dilakukan dengan alat yang disebut dengan dialyzer dengan melakukan proses penyaringan zat yang sudah tidak diperlukan diluar tubuh, sedangkan peritoneal dialysis merupakan penyaringan zat racun uremik melalui perut (Pernefri, 2011). Tindakan medis yang sering dilakukan pada pasien dengan PGK ialah hemodialisis (HD). Tindakan medis tersebut dapat memicu terjadinya anemia, hal tersebut terjadi karena disebabkan oleh sejumlah kecil darah tetap berada di dialiser, selain itu anemia pada PGK terjadi karena adanya kerusakan pada bagian ginjal yang menjadi tempat produksi hormon Erythropoietin Stimulating Agent (ESA) yaitu pada fibroblast interstisial korteks renalis, hal tersebut menyebabkan terjadinya gangguan produksi hormon ESA, dimana hormon tersebut berupa glikoprotein yang berfungsi menstimulasi produksi sel-sel darah merah di sumsum tulang belakang dan bekerja dengan mengikat reseptor ESA homodimer, akibat gangguan tersebut menyebabkan defisiensi erythropoietin sehingga produksi sel-sel darah merahpun tidak terbentuk (Sudhana, 2017). Selain itu ada beberapa penyab lain yang menimbulkan kejadian anemia pada PGK seperti terjadinya kekurangan zat besi dan adanya inflamasi kronik (Hidayat et all, 2016). Di Indonesia belum ada data epidemiologi nasional tentang anemia pada pasien PGK, namun berdasarkan data RSUD dr. Cipto Mangunkusumo yang diadakan di Jakarta pada tahun 2010 untuk pertama kalinya mendaftarkan 100\% pasien baru hemodialisis dengan anemia dengan kadar hemoglobin rata-rata 7,7 g/ dL (Pernefri, 2011). Sebuah penelitian Sanjaya, et al (2019) yang dilaksanakan di RS Sanglah, ditemukan bahwa dari 54 pasien penderita penyakit ginjal kronik terdapat 52 kasus anemia yaitu sebesar 96,3\% dari total kasus pasien PGK.

Berdasarkan penelitian di RSUD Tangerang terkait penilaian pemakaian obat anemia pada PGK yang menjalani hemodialisis diperoleh hasil berdasarkan ketepatan pasien $(100 \%)$, ketepatan indikasi (100\%), ketepatan dosis (100), dan ketepatan obat (96\%) (Megawati et all, 2020). Penelitian lain dari Alkel et al (2017) menunjukan hasil masih terjadi perbedaan pemberian dosis terapi baik itu terapi eritropoietin maupun terapi besi terhadap resep dokter dan rekomendasi pada 
MEDFARM: Jurnal Farmasi dan Kesehatan, Vol. 10, No. 2, 2021, Hal, 1-12

e-ISSN : 2715-9957

p-ISSN: 2354-8487

pedoman Kidney Disease Outcome Quality Initiative (KDOQI) tahun 2012. Ketidaktepatan dalam pemberian terapi anemia pada PGK menjadi faktor penyebab penggunaan obat menjadi tidak rasional, sehingga menimbulkan kegagalan dalam terapi suatu penyakit. Saat ini masih banyak pasien anemia pada PGK yang mendapat pengobatan dengan erythropoietin dalam dosis yang tidak mengacu pada panduan yang ada, sehingga menyebabkan target $\mathrm{Hb}$ tidak tercapai dan pengobatan menjadi lebih lama pada terapi anemia pada PGK.

Menurut Somvanshi (dikutip dalam Sanjaya et al, 2019) menyatakan bahwa penderita PGK dengan anemia dapat menyebabkan beberapa komplikasi seperti timbulnya penyakit kardiovaskular, jantung berdebar saat beraktivitas, pembesaran otot jantung, hingga gagal jantung karena jantung tidak bisa mengalirkan cukup darah ke seluruh tubuh. Akibat komplikasi tersebut mempengaruhi meningkatnya angka kematian, angka kesakitan, melemahnya fungsi tubuh, kualitas hidup, serta peningkatan biaya pengobatan pasien akibat meningkatnya waktu perawatan pasien (Adiatma, 2014). Sehingga penelitian ini dilakukan untuk melakukan perbandingan kesesuaian pengobatan yang diberikan pada pasien PGK terhadap pedoman yang berlaku.

\section{METODOLOGI PENELITIAN}

Penelitian ini termasuk penelitian observasional deskriptif yang menggunakan desain cross sectional dan dilaksanakan pada unit rekam medis RSU Ari Canti di Jl. Raya Mas Ubud Gianyar pada bulan February-April 2021. Pengambilan data dilakukan secara retrospektif pada data rekam medis 80 pasien dengan teknik purposive sampling. Kriteria pemilihan sampel dari penelitian ini ialah pasien yang mendapat perawatan hemodialisis seminggu dua kali secara rutin, pasien dengan nilai hemoglobin $<12 \mathrm{~g} / \mathrm{dl}$ untuk perempuan dan $<13 \mathrm{~g} / \mathrm{dl}$ untuk lakilaki dan pasien yang menerima obat anemia yang telah diresepkan oleh dokter. Penelitian ini diawali dengan tahap pertama yaitu pengurusan ijin penelitian, dan tahap kedua dilakukan pemeriksaan terhadap data rekam medis pasien yang menjalani hemodialisis, dari data tersebut dilakukan pemilihan sampel penelitian yang memenuhi kriteria inklusi. Pada tahap ketiga dilakukan pencatatan terkait data yang diperlukan dalam penelitian seperti data demografi, data penunjang dan data obat anemia yang diterima pasien. Tahap akhir 
MEDFARM: Jurnal Farmasi dan Kesehatan, Vol. 10, No. 2, 2021, Hal, 1-12

e-ISSN : 2715-9957

p-ISSN: 2354-8487

dilakukan pengolahan data hasil pengamatan secara univariat dengan menggunakan Microsoft excel, dimana data yang diperoleh ditampilkan dan dilaporkan dalam bentuk persentase yang dimuat dalam tabel, angka dan pemberian penjelasan.

\section{HASIL DAN PEMBAHASAN}

Karakteristik Subjek Penelitian

Tabel 1. Karakteristik Subjek Penelitian

\begin{tabular}{|c|c|c|c|}
\hline \multicolumn{2}{|c|}{ Karakteristik Pasien } & $\begin{array}{l}\text { Frekuensi } \\
\text { (f) }\end{array}$ & $\begin{array}{c}\text { Persentase } \\
(\%)\end{array}$ \\
\hline \multirow{6}{*}{ Usia } & 20-30 tahun & 1 & $1,25 \%$ \\
\hline & 31-40 tahun & 4 & $5 \%$ \\
\hline & 41-50 tahun & 23 & $28,75 \%$ \\
\hline & 51-60 tahun & 28 & $35 \%$ \\
\hline & 61-70 tahun & 17 & $21,25 \%$ \\
\hline & 71-80 tahun & 7 & $8,75 \%$ \\
\hline \multirow[t]{2}{*}{ Jenis Kelamin } & Pria & 53 & $66,25 \%$ \\
\hline & Wanita & 27 & $33,75 \%$ \\
\hline \multicolumn{4}{|l|}{ Penyakit } \\
\hline \multirow[t]{8}{*}{ Penyerta } & Hipertensi & 71 & $35,3 \%$ \\
\hline & HF (Heart Failure) & 20 & $10,0 \%$ \\
\hline & DM & 14 & $7,0 \%$ \\
\hline & Pnemonia & 3 & $1,5 \%$ \\
\hline & Asidosis Metabolik & 63 & $31,3 \%$ \\
\hline & Asam Urat & 12 & $6,0 \%$ \\
\hline & Dispepsia & 14 & $7,0 \%$ \\
\hline & Dislipidemia & 4 & $2,0 \%$ \\
\hline \multirow{5}{*}{$\begin{array}{l}\text { Rentang Nilai } \\
\text { Hemoglobin }\end{array}$} & Ringan (Wanita:11,0-11,9g/dl \& Pria & & \\
\hline & $: 11,0-12,9 \mathrm{~g} / \mathrm{dl})$ & 2 & $2,5 \%$ \\
\hline & Sedang (Pria \& Wanita 8,0-10,9 & & \\
\hline & $\mathrm{g} / \mathrm{dl})$ & 55 & $68,75 \%$ \\
\hline & Berat (Pria \& Wanita $<8,0 \mathrm{~g} / \mathrm{dl}$ ) & 23 & $28,75 \%$ \\
\hline
\end{tabular}

Karakteristik Subjek Berdasarkan Usia

Berdasarkan karakteristik usia pada penelitian ini menunjukan hasil bahwa pasien yang mengalami penyakit ginjal kronik dengan anemia dialami oleh golongan usia 51-60 tahun dengan persentase tertinggi (35\%), dan yang terendah terjadi pada golongan usia 20-30 tahun dengan persentase (1,25\%). Bersadarkan literatur menyatakan bahwa usia menjadi salah satu pencetus timbulnya penyakit gagal ginjal kronik, dimana dengan bertambahnya usia, kemampuan ginjal juga akan berkurang, dan umumnya terjadi pada usia 40 tahun keatas 
MEDFARM: Jurnal Farmasi dan Kesehatan, Vol. 10, No. 2, 2021, Hal, 1-12

e-ISSN : 2715-9957

p-ISSN: 2354-8487

(Hartini, 2016). Dalam usia diatas tersebut biasanya secara alamiah ginjal mengalami proses berkurangnya sejumlah nefron yang dapat menyebabkan penurunan fungsi ginjal sebesar $10 \%$, dan hal tersebut diperkirakan sudah mengalami kerusakan pada ginjal katagori ringan yaitu penurunan nilai LFG menjadi 60-89 ml/menit/1,73 m2 (Veronika \& Hartono, 2019).

Karakteristik Subjek Bersasarkan Jenis Kelamin

Berdasarkan hasil penelitian menunjukan bahwa menurut karakteristik jenis kelamin, kejadian anemia pada PGK paling banyak terjadi pada subjek penelitian pria yaitu sejumlah 53 orang $(66,25 \%)$ dan wanita sejumlah 27 orang $(33,75 \%)$. Penelitian lain mengungkapkan bahwa tingkat kejadian PGK pada pria cenderung lebih besar dikarenakan mereka memiliki gaya hidup yang lebih berisiko menyebabkan gagal ginjal seperti kebiasaan merokok, minuman keras, di mana hal itu menyebabkan ginjal bekerja lebih keras (Hartini, 2016). Penelitian lain juga menunjukan hasil yang sesuai dengan penelitian ini dimana kejadian PGK lebih banyak terjadi pada pria yaitu sebesar (63,5\%) dibandingkan dengan wanita yaitu sebesar (36,5\%) (Rukmaliza, 2013).

Karakteristik Subjek Berdasarkan Penyakit Penyerta

Berdasarkan hasil penelitian menunjukan bahwa karakteristik subjek penelitian berdasarkan penyakit penyerta pasien terdapat 3 besar penyakit yang paling mendominasi yaitu, hipertensi sebesar (35,5\%), asidosis metabolic (31,3\%) dan HF (Heart Failure) (10,0\%). Hipertensi pada PGK diakibatkan karena kehilangan nefron fungsional yang progresif dalam jumlah besar, hal tersebut menyebabkan interaksi yang seperti peningkatan aliran darah, peningkatan LFG (Laju Filtrasi Glomerulus), dan peningkatan keluarnya urin dari nefron. Perubahan kerja ginjal setelah beberapa waktu akan menyebabkan kerusakan lebih lanjut dengan penurunan tambahan kapasitas ginjal dan berkembang menjadi infeksi ginjal terminal (Hartini, 2016). Asidosis metabolik merupakan komplikasi yang khas pada pasien dengan PGK terutama pada pasien dengan LFG dibawah $25 \mathrm{~mL} / \mathrm{min} / 1,73 \mathrm{~m} 2$ (Septiani, 2017).

Karakteristik Subjek Berdasarkan Nilai Hemoglobin

Berdasarkan hasil penelitian menunjukan bahwa menunjukan hasil bahwa terdapat pasien yang mengalami anemia ringan pada pasien PGK sebesar $(2,5 \%)$, anemia sedang sebesar $(68,75 \%)$ dan anemia berat sebesar $(28,75 \%)$. 
MEDFARM: Jurnal Farmasi dan Kesehatan, Vol. 10, No. 2, 2021, Hal, 1-12

e-ISSN : 2715-9957

p-ISSN: 2354-8487

Rendahnya jumlah hemoglobin dalam eritrosit menunjukan kejadian anemia, dan hal tersebut menyebabkan kemampuan eritrosit menurun dalam membawa oksigen ke seluruh jaringan (Gunandi et al, 2016).

Karakterisasi Pola Penggunaan Obat Anemia Pada Pasien PGK

Pada karakteristik pola penggunaan obat anemia pada pasien PGK dengan hemodialisis disajikan dalam tabel berikut:

Tabel 2. Data Penggunaan Obat Anemia Pengobatan Tunggal Dan Kombinasi Di RSU Ari Canti Pada Tahun 2020

\begin{tabular}{cccc}
\hline Terapi & Rute & Frekuensi (f) & Persentase (\%) \\
\hline Monoterapi & & & \\
Epoetin Alfa & SC & 52 & $65 \%$ \\
Iron & IV & 7 & $8.75 \%$ \\
\hline Kombinasi 2 Obat & SC & 19 & $23,8 \%$ \\
Epoetin Alfa + & Oral & & $2,5 \%$ \\
Asam Folat & IV & 2 & \\
Iron + & Oral & & \\
Asam Folat & &
\end{tabular}

Berdasarkan hasil penelitian menyatakan bahwa pasien yang memperoleh pengobatan tunggal sebanyak 59 orang (73,75\%) dimana 52 orang (65\%) menerima terapi epoetin alfa dan 7 orang lagi $(8,8 \%)$ menerima terapi iron. Pasien yang menerima terapi kombinasi sebanyak 21 orang $(26,25 \%)$, dimana kombinasi masing-masing yaitu, 19 orang $(23,8 \%)$ menerima kombinasi antara epoetif alfa dan asam folat, 2 orang (2,5\%) menerima kombinasi iron dan asam folat. Pada kasus penyakit ginjal kronik, ginjal tidak memproduksi banyak sel-sel darah merah sehingga pasien mengalami defisiensi eritropoetin, pemberian terapi Erythropoietin Stimulating Agents (ESA) menjadi pengobatan lini pertama dalam penanganan anemia pada PGK untuk mengganti kekurangan eritropoetin. ESA berperan dalam menstimulasi deferensiasi eritroid progenitor stem sel dan menginduksi pelepasan retikulosid dari sumsum tulang ke peredaran darah (Kurniawanto et al, 2018). Pemberian iron bertujuan untuk mencukupi status besi pasien sehingga pemberian eritropoetin dapat direspon secara optimal (Pernefri, 2011). Pemberian asam folat pada kombinasi pengunaan dua obat pada kasus ini 
MEDFARM: Jurnal Farmasi dan Kesehatan, Vol. 10, No. 2, 2021, Hal, 1-12

e-ISSN : 2715-9957

p-ISSN: 2354-8487

merupakan salah satu terapi penunjang yang memiliki peran dalam meningkatkan optimalisasi terapi ESA (Pernefri, 2011).

Evaluasi Ketepatan Pemakaian Obat Anemia Pada Pasien Penyakit Ginjal Kronik (PGK)

Hasil evaluasi ketepatan pemakaian obat anemia pada pasein PGK dengan hemodialisis disajikan dalam gambar berikut:

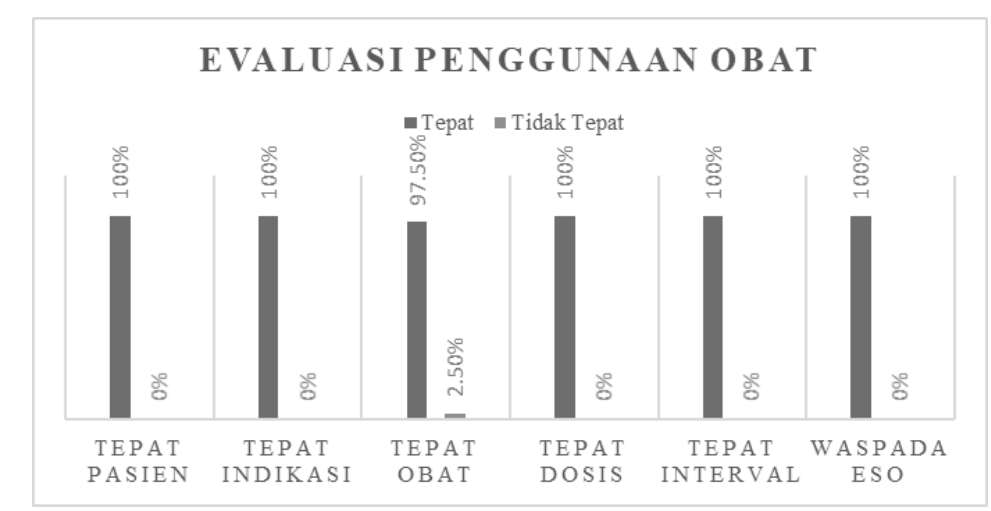

Gambar 1. Grafik Evaluasi Ketepatan Penggunaan Obat anemia

Penggunaan obat anemia pada pasien PGK dengan hemodialisis dievaluasi menurut enam kriteria yaitu ketepatan pasien, ketepatan indikasi, ketepatan obat, ketepatan dosis, ketepatan interval waktu pemberian dan kewaspadaan efek samping.

\section{a) Tepat Pasien}

Tepat pasien ialah ketepatan dalam pemilihan obat menurut pertimbangan kondisi klinis pasien sehingga tidak menimbulkan kontraindikasi kepada pasien (Sumawa et al, 2015) Berdasarkan hasil penelitian menunjukan bahwa dari 80 data rekam medis pasien yang menjadi sampel penelitian diperoleh nilai sebesar $(100 \%)$ telah memenuhi kriteria ketepatan pasien dimana semua pasien anemia dengan PGK yang menjalani hemodialisis telah menerima obat sesuai dengan kondisi klinis, serta tidak menyebabkan kontraindikasi untuk pasien.

b) Tepat Indikasi

Evaluasi ketepatan indikasi penggunaan obat anemia pada PGK merupakan proses penilaian pemberian terapi yang sesuai dengan kebutuhan pasien yang didasarkan atas diagnosa dokter (Sumawa et al, 2015\%. Evaluasi ketepatan indikasi ini penting untuk dilakukan, dikarenakan jika obat diberikan kepada pasien tanpa gejala yang sesuai, manifestasi pasien tidak akan berkurang atau 
MEDFARM: Jurnal Farmasi dan Kesehatan, Vol. 10, No. 2, 2021, Hal, 1-12

e-ISSN : 2715-9957

p-ISSN: $2354-8487$

hilang (Andriyana, 2018). Berdasarkan hasil penelitian menunjukan bahwa dari 80 sampel rekam medis yang diteliti diperoleh hasil sebesar (100\%) sampel memenuhi kriteria tepat indikasi. Seluruh sampel telah menerima obat yang tepat berdasarkan diagnosa adanya penyakit anemia yang dilihat dari hasil pemeriksaan laboratorium pasien yaitu kadar hemoglobin, saturasi transferin dan ferritin serum pasien.

c) Tepat Obat

Penilaian ketepatan pemilihan obat dilakukan berdasarkan perbandingan yang dilakukan terhadap kesesuaian pemilihan obat dengan drug of choicenya. Pada penelitian ini evaluasi ketepatan penggunaan obat anemia dilaksanakan dengan melakukan perbandingan terhadap obat anemia yang diterima pasien dengan pedoman standar yang berlaku di Rumah Sakit Umum Ari Canti yaitu PERNEFRI. Berdasarkan hasil penelitian di dapatkan bahwa dari 80 sampel data rekam medis yang diteliti terdapat 78 sampel data rekam medis (97,5\%) memenuhi kriteria tepat obat dan 2 sampel data rekam medis (2,5\%) yang tidak tepat obat. Ketidaktepatan pemilihan obat terjadi pada 2 sampel data medik pasien yang mengalami anemia defisiensi besi absolut dengan nilai saturasi transferin $<20 \%$ dan ferritin serum $<200 \mathrm{ng} / \mathrm{ml}$. Berdasarkan pedoman yang berlaku di Rumah Sakit Ari Canti, pasien PGK yang mengalami anemia defisiensi besi absolut harusnya menerima terapi besi fase koreksi dengan dosis 100mg setiap 2 kali seminggu selama sepuluh kali dan terapi epoetin ditunda terlebih dahulu sampai status besi pasien tercukupi, sedangkan pada kasus pada penelitian ini pasien mendapatkan terapi epoetin pada keadaan anemia defisiensi besi absolut.

d) Tepat Dosis

Penilaian ketepatan dosis dilakukan berdasarkan besaran dosis obat anemia yang diterima pasien lalu dibandingkan pada acuan standar yang ada di RSU Ari Canti. Pada penilaian ini diperoleh hasil bahwa dari 80 sampel data rekam medis yang telah diteliti semua sampel telah memenuhi kriteria ketepatan dosis sehingga hasilnya menunjukan hasil 100\%.

e) Tepat Interval Waktu Pemberian

Interval waktu pemberian obat ialah rentang waktu pemberian antara obat awal dan obat selanjutnya (Depker RI, 2011). Berdasarkan hasil penelitian 
MEDFARM: Jurnal Farmasi dan Kesehatan, Vol. 10, No. 2, 2021, Hal, 1-12

e-ISSN : 2715-9957

p-ISSN: 2354-8487

menunjukan bahwa dari 80 sampel data menghasilkan ketepatan sebesar (100\%). Interval pemberian terapi anemia pada pasien PGK disesuaikan dengan kebutuhan pasien, sehingga setiap yang menerima terapi anemia baik itu epoetin alfa maupun iron tidak selalu memiliki interval waktu yang sama.

f) Waspada Efek Samping

Setiap pemberian obat memiliki potensi untuk menyebabkan efek samping. Reaksi efek samping akibat pemakaian erythropoietin alfa atau ESA (Erythropoietin Stimulating Agent) dengan persentase (>10\%) yaitu hipertensi, demam, sakit kepala, mual, muntah dan batuk, kejadian lainnya dengan persentase (1\%-10\%) yaitu edema, thrombosis, urticaria, kejang otot, serta reaksi lain dengan persentase $(<1 \%)$ yaitu kejadian alergi, anafilaksis, erythema dan hipersensitivitas. Sedangkan pemberian iron secara intravena juga dapat menyebabkan efek samping seperti hipotensi, sakit kepala, muntah dan mual $(>10 \%)$, reaksi lain seperti hipertensi, nyeri dada, kelelahan, demam, nyeri perut, gatal (1\%-10\%) serta reaksi yang mengancam jiwa seperti shock anaphylactic, bronchospasme (DIH, 2012). Hipertensi merupakan efek samping dengan persentase terbesar akibat penggunaan erythropoietin, sehingga perlu dilakukan monitoring tekanan darah baik selama hemodialisis maupun selama mendapatkan terapi ESA. Pada penelitian ini tidak ditemukan adanya kasus kejadian efek samping obat akibat pemberian obat anemia pada pasien PGK, yang artinya 80 orang yang masuk kedalam sampel penelitian telah memenuhi ketepatan dalam waspada efek samping obat.

\section{SIMPULAN}

Pola penggunaan obat anemia pada pasien PGK dengan hemodialisis ialah menggunakan terapi tunggal sebesar $(73,75 \%)$ dan terapi kombinasi 2 obat sebesar (26,3\%). Dengan obat yang dipakai ialah erythropoietin alfa, iron, dan folic acid. Berdasarkan hasil penilaian penggunaan obat anemia dari enam aspek diperoleh hasil, ketepatan pasien (100\%), ketepatan indikasi $(100 \%)$, ketepatan obat $(97,5 \%)$, ketepatan dosis $(100 \%)$, ketepatan interval waktu pemberian $(100 \%)$ dan kewaspadaan efek samping (100\%). 
MEDFARM: Jurnal Farmasi dan Kesehatan, Vol. 10, No. 2, 2021, Hal, 1-12

e-ISSN : 2715-9957

p-ISSN: 2354-8487

\section{DAFTAR PUSTAKA}

Adiatma, D.C. 2014. Prevalensi Dan Jenis Anemia Pada Pasien Penyakit Ginjal Kronik Yang Menjalani Hemodialisis Reguler. Jurnal Media Medika Muda. Semarang: Universitas Diponegoro.

Akel, M., Shamas, K., Sakr, F., Dabbous, M., Safwan, J., Cherfan, M., Iskandarini, M. Evaluation of the management of anemia in hemodialysis patients in Lebanon. J Nephropharmacol.

American Pharmacist Association. 2012. Drug Information Handbook with International Trade Name Index 21st edition, Ohio: Lexicomp.

Andriyana, N.D. 2018. Evaluasi Terapi Penggunaan Obat Antihipertensi pada Pasien Geriatri di Instalasi Rawat Inap RSUD Dr. Moewardi Surakarta Tahun 2016. Surakarta: Universittas Muhamadiyah Surakarta.

Depkes RI. 2011. Modul Penggunaan Obat Rasional. Jakarta: Kemenkes RI.

Dipiro J.T., Wells B.G., Schwinghammer T.L. 2015. Pharmacotherapy Handbook, Ninth Edit., McGraw-Hill Education Companies, Inggris.

Gunandi, V.I.R., Mewo, Y.M., dan Tiho, Murniati. 2016. Gambaran Kadar Hemoglobin pada Pekerja Bangunan. Fakultas Kedokteran Universitas Sam Ratulangi Manado, Volume 4.

Hartini, S. 2016. Gambaran Karakteristik Pasien Gagal Ginjal Kronis Yang Menjalani Hemodialisis Di Rumah Sakit Umum Daerah Dr. Moewardi. Surakarta: Universitas Muhamadiyah Surakarta.

Hidayat, R., Azmi, S., Pertiwi, D. 2016. Hubungan Kejadian Anemia dengan Penyakit Ginjal Kronik pada Pasien yang Dirawat di Bagian Ilmu Penyakit Dalam RSUP dr M Djamil Padang Tahun 2010. Fakultas Kedokteran Universitas Andalas Padang. Jurnal Kesehatan Andalas.

Kurniawanto, R., Ulfa, NM., Hartono, R., 2018. Studi Profil Penggunaan Eritropoetin (Epo) Pada Pasien Penyakit Ginjal Kronis (Pgk) Yang Menjalani Hemodialisis Di Rumah Sakit Bhayangkara H.S. Samsoeri Mertojoso Surabaya. Akademi Farmasi Surabaya.

Lilia, I.H., dan Supadmi, W. 2019. Faktor Risiko Penyakit ginjal kronik Pada Unit Hemodialisis Rumah Sakit Swasta di Yogyakarta. Majalah Farmasetika 4.

Megawati, S., Restudiarti, A., Kurniasih, S. 2020. Evaluasi Penggunaan Obat Anemia Pada Pasien Gagal Ginjal Kronik Yang Menjalani Hemodialisis di Rumah Sakit Umum Kabupaten Tangerang Tahun 2018: Farmagizine journal. Vol VII No 2.

Pernefri. 2011. Konsensus Manajemen Anemia Pada Pasien Penyakit Ginjal Kronik. Jakarta.

Rukmaliza. 2013. Hubungan Karakteristik Individu Dengan Kualitas Hidup Pasien Gagal Ginjal Kronik Yang Menjalani Hemodialisis di Instalasi Dialisis BLUD RSU DR. Zainoel Abidin Banda Aceh Tahun 2013. Universitas Syah Kuala. 
MEDFARM: Jurnal Farmasi dan Kesehatan, Vol. 10, No. 2, 2021, Hal, 1-12

e-ISSN : 2715-9957

p-ISSN: 2354-8487

Sanjaya, A.A.G.B., Dharma shanti, D.G.D., Lestari, A.A.W. 2019. Gambaran Anemia Pada Pasien Penyakit Ginjal Kronik Di RSUP Sanglah Pada Tahun 2016. DOAJ: Jurnal Medika Udayana, Vol. 8 No. 6, Juni, 2019.

Septiani, A.M. 2017. Studi Penggunaan Natrium Bikarbonat Pada Pasien Gagal Ginjal KronikDengan Asidosis Metabolik (Penelitian Di Rumah Sakit Umum Daerah Sidoarjo). Universitas Muhamadiyah Malang.

Sudhana, I Wayan. 2017. Pathogenesis Anemia Pada Penyakit Ginjal Kronik. Denpasar : SMF Ilmu Penyakit Dalam FK Unud/RSUP Sanglah

Sumawa, P.M.R., Adeanne, C.W., \& Paulina, V.Y.Y. 2015. Evaluasi Kerasionalan Penggunaan Obat Antihipertensi Pada Pasien Hipertensi Rawat Inap Di RSUP Prof. Dr. R.D. Kandou Manado Periode Januari-Juni 2014. Jurnal Ilmiah Farmasi: UNSRAT. Manado.

Veronika, E., \& Hartono, B. 2019. Nilai Estimasi Glomerulus Filtration Rate (GFR) Menggunakan Persamaan Cockcroft And Gault Pada Masyarakat Terpajan Merkuri Di Area Pertambangan Emas Skala Kecil (Pesk) Desa Lebaksitu Kabupaten Lebak Banten. Universitas Indonesia: Forum Ilmiah Volume 16 Nomor 2. 